\title{
Keunikan Penamaan Jurnal Perpustakaan dan Informasi PTKIN: Kajian Semantik
}

\author{
Kardi $^{1, *}$, Bahrul Ulumi ${ }^{2}$ \\ ${ }^{1}$ Institut Agama Islam Negeri Ponorogo, Indonesia \\ ${ }^{2}$ Universitas Islam Negeri Walisongo Semarang, Indonesia
}

Paper type:

Research article

\section{Article history:}

Received April 4, 2021

Revised October 19, 2021

Accepted October 23, 2021

Keywords:

- Online journal

- Library and information

- OJS

- PTKIN

- Name

\section{Abstract}

Introduction. This article describes the names of scientific publications journals in the field of libraries and information, which are increasing in number, and the increasing activity of publishing scientific works that encourage librarians to develop writing habits.

Methodology. This article employs a qualitative descriptive semantic approach by using various multi-site names of library journals and information in the PTKIN environment. The focus of this paper lies in the uniqueness of naming library and information journals in the PTKIN environment.

Results and discussion. The results showed that the journal's name contains terms derived from Indonesian, local languages, and foreign languages. In addition, there is also the name of the journal, which is an abbreviation of letters that makes it easy to recognize.

Conclusion. The names of library and information journals in the PTKIN environment tend to contain the meaning of university libraries in a general sense or things related to library materials.

\section{Pendahuluan}

Istilah "publish or perish" bisa menjadi motivasi bagi siapa saja yang ingin membiasakan diri menulis dan menyebarluaskan hasil tulisan tersebut kepada publik sehingga mereka bisa mendapatkan pengetahuan, sementara bagi penulis bisa menumbuhkan tradisi kepenulisan. Terlebih, dengan tumbuhnya platform pengelolaan jurnal ilmiah seperti online journal systems (OJS) yang memungkinkan asosiasi profesi ataupun lembaga pendidikan membuat jurnal untuk menerbitkan karya ilmiah. Dewasa ini, berbagai macam jurnal ilmiah bisa tumbuh pesat karena adanya regulasi dari pemerintah, yaitu Dikti yang mewajibkan mahasiswa dari semua strata dari S1 sampai dengan S3 untuk mempublikasikan karya ilmiahnya di jurnal (Lukman et.al., 2015).

Regulasi ini juga berlaku untuk perguruan tinggi yang membuka program studi ilmu perpustakaan dan informasi. Mereka dituntut menerbitkan jurnal sebagai wadah bagi para pengajar dan mahasiswa untuk mempublikasikan karya ilmiah mereka guna penyebaran pengetahuan.

Selama ini, ada dua isu utama yang dihadapi oleh editor jurnal ilmiah, yaitu minimnya ketersediaan manuskrip yang berkualitas dan keberlangsungan (sustainability) pengelolaan jurnal ilmiah (Hariyanto, 2016). Hal tersebut bisa terjadi karena banyak

\footnotetext{
${ }^{*}$ Corresponding author.

Email addresses: kardi@iainponorogo.ac.id (Kardi), bahrul.ulumi@walisongo.ac.id (B. Ulumi)
} 
penulis yang cenderung selektif memilih jurnal. Mereka cenderung memilih reputasi jurnal baik peringkat SINTA atau Scopus.

Tren publikasi jurnal ilmiah di era online journal systems (OJS) menjadi momentum untuk mendorong minat menulis bagi semua profesi termasuk di dalamnya pustakawan. Pustakawan memiliki keterampilan yang diperlukan untuk berpartisipasi dalam penerbitan jurnal ilmiah dan merekomendasikan keterampilan literasi penerbitan untuk menunjukkan nilai pustakawan dalam proses penerbitan jurnal ilmiah (Ndungu, 2020); (Farmanbar \& Kolstrup, 2020).

Jurnal perpustakaan ada yang lahir dari lingkungan perpustakaan perguruan tinggi dan juga yang dari program studi ilmu perpustakaan dan informasi. Menariknya, masingmasing memiliki ciri khas dalam memberikan nama jurnal tersebut dengan berbagai alasan sebagai pijakan dan penyemangat pengelola untuk mentradisikan dalam menulis.

Biarpun sebagian orang mengatakan apalah arti sebuah nama. Namun nama jurnal ini penting dan bisa menjadi penyemangat tersendiri bagi pengelola sesuai dengan namanama yang dibuatnya. Penamaan jurnal tentu bukan tanpa alasan. Pengelola jurnal mempunyai motivasi tertentu dalam memberikan nama jurnalnya. Artikel ini akan membahas penamaan jurnal perpustakaan dan informasi di lingkungan PTKIN di Indonesia. Hal ini penting untuk membatasi kajian dalam tulisan ini. Penelitian lain yang terkait dengan kajian keunikan nama di antaranya ada nama-nama mahasiswa, kota dan nama makanan (Oktavianingsih, 2019; Amirulloh, 2017; Khotimah \& Febriani, 2019).

\section{Metode Penelitian}

Penelitian ini adalah deskriptif kualitatif. Metode ini dirasa paling tepat untuk menggali nama-nama yang diberikan oleh pendiri atau pengelola (editorial board) kepada jurnal yang mereka kelola. Sepertinya, penamaan jurnal identik dengan pemberian nama pada anak yang baru lahir. Pemberian nama tersebut diharapkan membawa keberkahan dan keselamatan bagi pemilik nama. Sebagaimana sebuah artikel jurnal ilmiah yang membahas tentang kajian semantik dalam pemberian nama anak mengandung maksud tertentu (Khotimah \& Febriani, 2019).

Adapun pengumpulan data terkait dengan penamaan didasarkan pada interview pada editor in chief maupun editor. Disamping itu, untuk melengkapi hasil wawancara, penulis menggunakan referensi yang bersumber dari buku atau sumber lainnya yang mendukung pemahaman terhadap makna nama.

\section{Hasil dan Pembahasan}

\subsection{Jurnal Kajian Ilmu Perpustakaan dan Informasi di PTKIN}

Jurnal publikasi ilmiah di lingkungan PTKIN mulai ada sejak Kementerian Agama mengirim sarjana S1 khusus dari Universitas Indonesia pada tahun 1996. Setelah itu kemudian muncul jurnal al-Maktabah (1999) yang dikelola oleh perpustakaan IAIN Syarif Hidayatullah Jakarta waktu itu. Kemudian disusul jurnal Fihris perpustakaan IAIN Sunan Kalijaga Yogyakarta (2006) dan Pustakaloka jurnal ilmiah perpustakaan STAIN Ponorogo (2009). Namun seiring dengan berkembangnya waktu dan ilmu pengetahuan dan teknologi maka muncul sejumlah program studi (prodi) ilmu perpustakaan dan informasi di beberapa PTKI tertentu. Hal ini kemudian mendorong prodi-prodi tersebut membuat publikasi jurnal ilmiah perpustakaan dan informasi. Salah satu alasan pengembangan 
jurnal ilmiah ini juga karena hadirnya online journal systems (OJS) yang membantu pengelola jurnal secara lebih profesional menuju capaian jurnal yang bereputasi.

Reputasi jurnal bisa dilihat pada seberapa berpengaruh publikasi jurnal tersebut bisa dilihat pada ranking SINTA atau kualifikasi pada Scopus atau juga bisa dilihat pada Google Scholar Metrics (Allo \& Ahmad, 2020). Reputasi jurnal menjadi gengsi prestisius bagi perguruan tinggi sehingga perhatian pimpinan perguruan semua tertuju pada program pengelolaan jurnal yang baik dan profesional (Suroyo \& Tanaamah, 2016). Demikian halnya dengan pengembangan jurnal perpustakaan dan informasi di lingkungan PTKIN. Berikut ini adalah nama beberapa jurnal ilmiah yang berada di bawah Perguruan Tinggi Keagamaan Islam Negeri (PTKIN) yang telah masuk dalam daftar indeks SINTA mulai dari SINTA 2 hingga SINTA 6 (lihat Tabel 1).

Tabel 1. Nama-nama Jurnal Perpustakan dan Informasi di lingkungan PTKIN

\begin{tabular}{|c|c|c|c|c|c|}
\hline No & Jurnal & Afiliasi & Sinta & Terbit/ Tahun & Terbit Pertama \\
\hline 1 & $\begin{array}{l}\text { KHIZANAH Al-HIKMAH: Jurnal } \\
\text { Informasi, Arsip, dan Perpustakaan }\end{array}$ & UIN Alaudin Makasar & 2 & $2 x$ & 2013 (online) \\
\hline 2 & $\begin{array}{l}\text { PUSTAKALOKA: Jurnal Kajian } \\
\text { Informasi dan Perpustakaan }\end{array}$ & IAIN Ponorogo & 3 & $2 \mathrm{x}$ & 2009 (Printed) \\
\hline 3 & TIK ILMEU & IAIN Curup & 4 & $2 \mathrm{x}$ & 2017 (online) \\
\hline 4 & МАКТАВАН & UIN Syahid Jakarta & - & $2 \mathrm{x}$ & 1999 (Printed) \\
\hline 5 & $\begin{array}{l}\text { IQRA' }^{\prime} \text { Jurnal Perpustakaan dan } \\
\text { Informasi }\end{array}$ & UIN Sumatera Utara & 4 & $2 \mathrm{x}$ & 2014 (online) \\
\hline 6 & LIBRARIA & IAIN Kudus & 4 & $2 \mathrm{x}$ & 2014 (online) \\
\hline 7 & PUSTABIBLIA & IAIN Salatiga & 5 & $2 \mathrm{x}$ & 2017 (online) \\
\hline 8 & LIBRIA & UIN Ar-Raniri & 5 & $2 \mathrm{x}$ & 2016 (online) \\
\hline 9 & SHAUT AL-MAKTABAH & UIN Imam Bonjol Padang & 6 & $2 \mathrm{x}$ & 2017 (online) \\
\hline 10 & FIHRIS & $\begin{array}{l}\text { UIN Sunan Kalijaga } \\
\text { Yogyakarta }\end{array}$ & 6 & $2 \mathrm{x}$ & $\begin{array}{l}2006 \text { (Printed) } \\
2020 \text { (online) }\end{array}$ \\
\hline
\end{tabular}

Sumber: Nama-nama jurnal yang diambil dan dirangkum oleh penulis dari SINTA (science and technology index)

Jurnal yang telah lama eksis belum tentu memiliki reputasi indeks SINTA yang baik karena semua itu tergantung pada proses pengelolaan yang profesional. Hal ini bisa dilihat pada pengelolaan jurnal Khizanah al-Hikmah UIN Alaudin Makasar yang menduduki SINTA 2 dan telah melewati para pendahulunya, yaitu al-Maktabah UIN Syarif Hidayatullah Jakarta, Fihris UIN Sunan Kalijaga Yogyakarta, dan Pustakaloka IAIN Ponorogo yang terhitung telah lebih dari 10 tahun mengelola jurnal.

\subsection{Semantik dalam Penetapan Nama Jurnal Ilmiah}

Sema merupakan kata dasar semantik yang bermakna lambang atau sign. Bentuk kata kerja dari sema ini adalah semaino yang berarti menandai atau melambangkan. Kata semantik sendiri pertama kali digunakan oleh ahli filologi dari Perancis, Michael Breal pada tahun 1883. Semantik punya dua komponen yang mengartikan, berwujud bentuk dan bunyi bahasa dan komponen yang diartikan atau makna dari komponen yang pertama. Semantik ini dimaknai sebagai ilmu tentang makna. Semantik juga ilmu tentang makna atau arti, dan semantik ini merupakan satu dari tiga tataran analisis bahasa yang terdiri atas fonologi, gramatikal, dan semantik (Amilia \& Anggraeni, 2017).

Nashihuddin \& Aulianto (2016) memberikan pandangan bahwa pengelola harus menyiapkan nama jurnal atau judul jurnal bila ingin menjadikan jurnalnya terakreditasi dan punya reputasi internasional. Ada beberapa penamaan jurnal yang dipandang tidak tepat. Lukman (2015) mengungkap ada 4 kesalahan dalam pemberian nama jurnal; pertama, penamaan jurnal yang mengacu pada nama program studi atau lembaga yang 
menaunginya. Nama jurnal model ini tidak mencerminkan kekhasan isi jurnal tersebut. Sebagai contoh Jurnal Jurusan Ilmu Kimia; Jurnal Jurusam Geografi; dan Jurnal STIE Semarang. Nama-nama tersebut lebih mencerminkan program studi bukan mencerminkan kajian ilmu yang menjadi cakupan isi suatu jurnal. Kedua, nama jurnal yang mencantumkan kata e baik pada awal maupun pada akhir nama. Huruf e merupakan singkatan dari elektronik yang mengacu pada perubahan media informasi dari cetak ke elektronik. Misalnya, E_Jurnal Kimia; E_Jurnal Matematika.

Ketiga, penamaan jurnal dengan akronim. Akronim merupakan singkatan atau kependekan yang berupa huruf atau suku kata yang dilafalkan sebagai kata yang wajar (Badan Pengembangan dan Pembinaan Bahasa, 2016a). Akronim ini memberikan keuntungan berupa kemudahan mengingat. Kendati demikian, pada sisi lain nama ini memberikan kesan buruk pada nama jurnal itu sendiri bila pemilihan istilah tidak tepat. Misalnya JIMAT yang merupakan akronim dari Jurnal Ilmiah Mahasiswa S1 Akuntansi. Nama ini tidak mencerminkan sesuatu yang akademik sebab dalam pergaulan sehari-hari, jimat merupakan barang atau tulisan yang ditempelkan pada tubuh, atau tempat tertentu karena dianggap punya kesaktian dalam menangkal bahaya. Nama tersebut tidak relevan dikaitkan antara jurnal ilmiah sebagai bagian dari karya ilmiah yang kebenarannya berdasar pada bukti ilmiah. Sementara, jimat dipahami sebagai pelindung yang tidak memiliki bukti ilmiah.

Keempat, nama jurnal ditulis secara tidak konsisten. Misalnya nama jurnal yang ada di cover tidak sama dengan yang ada di situs jurnal, bahkan dalam naskah jurnal. Misalnya jurnal "Masyarakat: Jurnal Sosiolo atau Sosiologi Masyarakat".

Berdasar pada regulasi akreditasi ilmiah yang diterbitkan oleh LIPI (2014) dan juga DIKTI (2014), semakin khusus nama suatu jurnal mencerminkan kedalaman keilmuan, semakin tinggi kualitas manuskrip dan nilai akreditasinya. Nama jurnal sebaiknya berupa istilah spesifik yang membuat jurnal mudah disebut ketika dijadikan sebagai acuan. Nama jurnal juga sebaiknya sudah dikenal dalam lingkungan terkait (LIPI, 2014). Dokumen SNI 19-1950-1990 menyebut bahwa nama jurnal seharusnya sederhana dan ringkas sehingga memudahkan bila dikutip (BSN, 1990).

Bila terdapat judul yang semakna dengan istilah asing, maka padanan Bahasa Indonesia harus ditulis lebih dulu. Misalnya Indeks Majalah Ilmiah Indonesia yang merupakan alih bahasa dari "Index of Indonesian Learned Periodicals". Disamping itu, penempatan judul pada setiap nomor halaman harus selalu seragam. Teks dan ejaannya harus tetap sama pada halaman kulit, halaman judul, daftar isi, dan indeks.

\subsection{Keunikan Nama Jurnal dalam Kajian Informasi dan Perpustakaan di Lingkungan PTKIN}

Sebenarnya, nama jurnal bisa saja dibuat lebih panjang selama judul tersebut menjelaskan kajian ilmu yang mencakup terbitan. Menurut SNI 191936-1990, judul tambahan merupakan penjelasan yang ditambahkan pada judul Jurnal. Nama-nama unik Jurnal Perpustakaan di PTKIN umumnya sebagai kekhasan dan punya makna spesifik. Beberapa jurnal perpustakaan dan informasi dengan menggunakan nama dari bahasa Arab seperti Al-Maktabahyang berarti perpustakaan. Kata tersebut oleh pengelola jurnal sangat tepat karena dikelola oleh Perpustakaan IAIN Syarif Hidayatullah Jakarta pada tahun 1999 yang waktu itu masih berbasis tercetak. Kehadiran Al-Maktabah merupakan upaya pustakawan untuk memiliki media yang bisa mengakomodasi karya tulis ilmiah mereka dalam bidang kajian ilmu perpustakaan dan informasi. Jadi kajian tidak semata untuk merefleksikan kasus yang ada di perpustakaan sebagai lembaga, namun juga wacana yang sedang banyak dibicarakan. 
Nama jurnal yang serupa dengan nama di atas adalah Shaut Al-Maktabah yang berarti suara perpustakaan. Dari sisi makna kamus suara merupakan bunyi yang keluar dari mulut manusia seperti ketika bercakap-cakap, menyanyi, tertawa dan menangis (Badan Pengembangan dan Pembinaan Bahasa, 2016b). Nama Shaut tentu tidak secara fisik bermakna suara yang dikeluarkan dari mulut, namun lebih dari itu bahwa suara juga diasosiasikan dengan ekspresi tertulis dari hasil pemikiran kritis dalam kajian ilmu perpustakaan dan informasi. Jurnal ini lahir di era online journal systems yang dikelola prodi ilmu perpustakaan dan informasi UIN Sumatera Utara.

Ada juga jurnal bernama Khizanah al-Hikmah yang berarti pertimbangan yang bijak (Karmila, 2020). Nama tersebut diberikan oleh pendiri awalnya yakni M. Quraisy Mathar dkk, yang terinspirasi dari nama perpustakaan multifungsi di masa Bani Abbasiyah, tepatnya pada masa pemerintahan Harun al-Rasyid. Dari sana, visi jurnal ini diharapakan menjadi media penyebarluasan tulisan ilmiah bidang Perpustakaan dan Informasi. Nama jurnal tersebut terinspirasi dari perpustakaan yang saat itu sangat megah baik dari sisi isi maupun fisiknya (Editor in chief of Khizanah al-Hikmah, komunikasi pribadi, 6 Oktober 2021).

Jurnal Iqra' mengacu pada bunyi ayat Al Qur' an surat Al Alaq ayat yang berarti "membacalah". Kata ini merupakan fiil amr yang digunakan untuk memerintah membaca. Iqra penting sekali karena kegiatan ini merupakan cara paling strategis untuk mendapatkan pengetahuan dan pengalaman. Dalam pandangan pemimpin redaksi jurnal Iqra, nama juga diambil sebagai cara mengundang orang untuk membaca (Editor in chief of IQRA' , komunikasi pribadi, 6 Oktober 2021).

Fihris berarti katalog atau daftar isi. Dalam kajian ilmu perpustakaan, ada sarana bibliografi yang sangat membantu pencari informasi untuk mencari informasi yang berawal dari katalog atau bibilografi yang keduanya merupakan sarana bibliografi.

Ternyata, nama-nama jurnal ilmu perpustakaan dan informasi lebih banyak menggunakan nama yang bila diterjemahkan ke Bahasa Indonesia bermakna hal-hal yang berkaitan erat dengan perpustaakaan dan bahan perpustakaan (library materials). Bahkan, ada yang secara verbal menyebut perpustakaan yang berarti gedung dan lembaganya sekalian.

Nama Jurnal perpustakaan dan informasi yang tidak menggunakan istilah bahasa Arab seperti di atas, secara etimologis juga punya makna serupa yaitu buku dan perpustakaan. Misalnya Pustabiblia, Pustakaloka, Libraria dan sebagainya.

Pustabiblia merupakan jurnal yang diterbitkan oleh perpustakaan IAIN Salatiga. Pustabiblia diambil dari dua kata yaitu pustaka dan biblia. Menurut pemimpin Editor in Chief Jurnal Pustabiblia, arti pustaka adalah ilmu dan biblia adalah wadahnya. Jadi pustabiblia ini bermakna ilmu yang ada dalam wadah, yaitu berupa jurnal. Naskah menjadi sangat krusial sebab bisa dijadikan sebagai media untuk mengikat ilmu sehingga siapa saja, dan generasi penerus bisa bisa mewarisi ilmu yang diikat dalam media tertentu (Editor in chief of Pustabiblia, komunikasi pribadi, 5 Oktober 2021).

Nama Pustakaloka untuk sebuah jurnal juga unik karena nama atau istilah ini tidak pernah dipakai untuk menamai sesuatu. Nama ini hanya diberikan untuk jurnal yang diterbitkan oleh perpustakaan IAIN Ponorogo. Pustaka berarti buku atau kitab, sedangkan loka adalah wadah yang menampung buku atau kitab. Dalam arti yang lebih luas, pustakaloka bermakna wadah kajian informasi, yang merupakan wadah bagi mereka yang ingin mempublikasikan karya ilmiahnya (Journal editor of Pustakaloka, komunikasi pribadi, 5 Oktober 2021).

Libraria merupakan nama jurnal yang diterbitkan oleh perpustakaan IAIN Kudus. Libraria ini berakar dari istilah library yang berarti perpustakaan. Menurut editor in chief jurnal ini, pemilihan nama jurnal di atas tidak bisa dipisahkan dari library itu sendiri bahwa jurnal dikelola oleh mereka yang ada di perpustakaan, yang secara potensial bisa 
memanfaatkan untuk meningkatkan kemampuan menulis ilmiah kajian ilmu perpustakaan dan informasi (Editor in chief of Libraria, komunikasi pribadi, 5 Oktober 2021).

Di luar penamaan jurnal yang menggunakan Bahasa Arab dan bahasa asing lainnya, ada juga yang menggunakan istilah dari bahasa daerah seperti; Tik Ilmeu, Daluang, dan lain-lain. Tik Ilmeu adalah jurnal perpustakaan IAIN Curup yang kurang lebih berarti thalabul ilmu atau mencari ilmu. Terminologi ini sejiwa dengan pesan agama agar semua orang laki dan perempuan wajib menuntut ilmu, kapanpun, dimanapun, dan pada usia berapaun.

Nama yang menarik lagi adalah jurnal yang baru terbit perdana pada April 2021 adalah Jurnal Daluang, dikelola perpustakaan UIN Walisongo Semarang. Dari sisi istilah, daluang merupakan bahan sejenis kertas yang beraasal dari kulit pohon papermulbery "Broussetia papyryfera Vent" yang dibuat dengan cara ditumbuk, diperam, dan dijemur di panas sinar matahari (Permadi, 2005). Terjemahan daluang yang paling sesuai dengan konteks saat ini adalah kertas. Pada abad ke 15 kertas punya pengaruh yang sangat luas terhadap persebaran karya imiah di dunia, ditandai dengan penemuan mesin cetak oleh Gutenberg. Nama jurnal Daluang dipilih dengan harapan bisa menyebarkan pegetahuan dengan cepat tanpa ada halangan apapun baik akses maupun biaya (Journal editor of Daluang, komunikasi pribadi, 6 Oktober 2021).

Kala terbit jurnal perpustakaan rata-rata punya pola yang sama, yaitu di bulan pertengahan dan akhir. Masih jarang jurnal yang menerbitkan lebih dari 2 kali dalam setahun, misalnya di setiap kuartal bulan. Tentu hal ini akan sangat membantu pustakawan yang kala terbit pada bulan-bulan di pertengahan dan akhir tahun.

\subsection{Fenomena Jurnal dan Aktivitas Pustakawan}

Kelahiran jurnal dalam satu dekade terakhir ini, membuat angin segar buat pustakawan dan program studi ilmu perpustakaan dan informasi yang terdiri atas para pengajar dan mahasiswanya. Kesempatan mengekspresikan karya mereka dalam suatu jurnal sangat terbuka lebar. Mereka bebas memilih jurnal apa yang secara potensial akan memuat tulisan mereka.

Bila menilik salah satu jurnal bidang perpustakaan dan informasi, sebut saja jurnal Pustakaloka yang dikelola oleh IAIN Ponorogo, bahwa pengelola tidak perlu kuatir akan kekurangan naskah. Banyak naskah atau manuskrip yang selalu tersedia mengingat banyak penulis di berbagai kalangan mengirimkan naskah ke redaktur jurnal ini. Hanya saja yang menjadi perhatian adalah para penulis adalah bukan dari kalangan pustakawan atau pengajar ilmu perpustakaan dan informasi. Sebagai ilustrasi, bahwa dalam dua tahun terakhir, hanya sekitar 20\% yang mengisi jurnal Pustakaloka. Prosentasi ini menunjukkan bahwa kepenulisan pustakawan tidak terlihat aktif.

Justru, yang terlihat aktif dalam pengiriman naskah jurnal adalah mahasiswa yang sedang menyusun skripsi. Mereka berbondong-bondang mengirim naskah ke Pustakaloka.

\section{Kesimpulan}

Nama-nama yang digunakan dalam penamaan jurnal beragam, dari bahasa Arab, bahasa bentukan dan bahasa sansekerta. Dari semua nama yang digunakan, ternyata punya mankna yang terkait erat dengan pepustakaan seperti membaca, ilmu pengetahuan, informasi, kebijaksanaan, sarana bibliografi, dan media lainnya yang digunakan untuk menyimpan informasi. 
Menjamurnya kelahiran jurnal menuntut pustakawan untuk punya pemahaman yang memadai terhadap proses dan sistem submit melalui OJS, karena pada saat yang sama harus melayani pemustaka dari berbagai kalangan tentang bagaimana cara melakukan submit artikel jurnal melalui OJS.

Di samping itu, pustakawan juga dituntut mampu memahami jurnal-jurnal yang sesuai dengan artikel yang akan disubmit agar sesuai core tema kajian jurnal. Sebagai tambahan, sebaiknya pustakawan mampu mempredikasi kala terbit dari jurnal tertentu sehingga bisa mempersiapkan artikel dengan baik dan tepat waktu dalam proses submit artikel.

Fakta yang yang tidak kalah penting bagi pustakawan adalah, bahwa ternyata menjamurnya jurnal-jurnal baru kajian ilmu perpustakaan dan informasi tidak serta merta meningkatkan kuantitas dan kualitas karya pustakawan yang diterbitkan dalam jurnal-jurnal tersebut.

\section{Daftar Pustaka}

Allo, K. P., \& Ahmad, L. O. I. (2020). Google Scholar Metrics, Pengaruhnya pada Jurnal Ilmiah. Khizanah al-Hikmah : Jurnal IImu Perpustakaan, Informasi, dan Kearsipan, 8(1), 97-104. https://doi.org/10.24252/kah.v8i1a10

Amilia, F., \& Anggraeni, A. W. (2017). Semantik: Konsep dan Contoh Analisis. Pustaka Abadi.

Amirulloh, M. (2017). Penggunaan Nama Kota Sebagai Nama Domain di Indonesia. Sosiohumaniora, 19(1), 8-17.

Badan Pengembangan dan Pembinaan Bahasa. (2016a). Akronim. Badan Pengembangan dan Pembinaan Bahasa, Kementerian Pendidikan, Kebudayaan, Riset, dan Teknologi Republik Indonesia. https://kbbi.kemdikbud.go.id/entri/akronim

Badan Pengembangan dan Pembinaan Bahasa. (2016b). Suara. Dalam KBBI daring. Badan Pengembangan dan Pembinaan Bahasa, Kementerian Pendidikan, Kebudayaan, Riset, dan Teknologi Republik Indonesia. https://kbbi.kemdikbud.go.id/entri/suara

BSN. (1990). SNI 19-1950-1990 tentang Terbitan Berkala. BSN.

DIKTI. (2014). Peraturan Dirjen DIKTI Nomor 1 Tahun 2014 Pedoman Akreditasi Terbitan Terbitan Berkala IImiah. DIKTI.

Editor in chief of IQRA'. (2021, Oktober 6). Arti nama jurnal IQRA' [Komunikasi pribadi].

Editor in chief of Khizanah al-Hikmah. (2021, Oktober 6). Arti istilah Khizanah al-Hikmah pada jurnal Khizanah al Hikmah. [Komunikasi pribadi].

Editor in chief of Libraria. (2021, Oktober 5). Arti Libraria pada jurnal Libraria yang diterbitkan oleh IAIN Kudus. [Komunikasi pribadi].

Editor in chief of Pustabiblia. (2021, Oktober 5). Arti nama jurnal Pustabiblia [Komunikasi pribadi].

Farmanbar, M., \& Kolstrup, P. (2020). Publishing with Open journal systems (OJS): The engaged university and library support at the University of Stavanger. Septentrio Conference Series, Query date: 2021-01-27 12:10:21. https://septentrio.uit.no/index.php/SCS/article/view/5604

Hariyanto, E. (2016). Qua Vadis the Quality of Online Scientific Journal Publishing in State Islamic University (PTKIN). Khizanah al-Hikmah Jurnal Ilmu Perpustakaan, Informasi, dan Kearsipan, 4(1), 76-90.

Journal editor of Daluang. (2021, Oktober 6). Makna dan harapan dengan nama daluang pada nama Jurnal Daluang [Komunikasi pribadi].

Journal editor of Pustakaloka. (2021, Oktober 5). Makna nama jurnal Pustakaloka [Komunikasi pribadi]. 
Karmila, A. K. (2020). Khizanah al-Hikmah: Jurnal Ilmu Perpustakaan, Infomasi, dan Kearsipan, How It Manages? Literatify : Trends in Library Developments, 1(1), 8 14. https://doi.org/10.24252/literatify.v1i1.13094

Khotimah, K., \& Febriani, I. (2019). Kajian Semantik Nama Diri Mahasiswa Madura di Prodi Pendidikan Bahasa dan Sastra Indonesia Universitas Trunojoyo Madura. Jurnal Pendidikan Bahasa dan Sastra Indonesia, 8(1), 51-55.

LIPI. (2014). Peraturan Kepala LIPI Nomor 3 Tahun 2014 Pedoman Akreditasi Terbitan Terbitan Berkala IImiah. LIPI.

Lukman. (2015). Manajemen penerbitan jurnal elektronik[Makalah presentasi]. Pelatihan Training of Trainer Manajemen Penerbitan Jurnal Elektronik, Jakarta.

Lukman, Marlina, E., Keumalasari, R., Akbar, A. H., \& Riyanto, S. (2015, Januari 8). Perkembangan Open Access Jurnal IImiah Indonesia. Pusat Data Dan Dokumentasi Ilmiah - Lembaga Ilmu Pengetahuan Indonesia. https://pddi.lipi.go.id/perkembangan-open-access-jurnal-ilmiah-indonesia/

Nashihuddin, W., \& Aulianto, D. R. (2016). Pengelolaan Terbitan Berkala Ilmiah Sesuai Ketentuan Akreditasi: Upaya Menuju Jurnal Trakreditasi Dan Bereputasi Internasional. Jurnal Pustakawan Indonesia, 15(1-2), Article 1-2. https://journal.ipb.ac.id/index.php/jpi/article/view/16921

Ndungu, M. W. (2020). Publishing with Open Journal Systems (OJS): A Librarian's Perspective. Serials Review. https://www.tandfonline.com/doi/abs/10.1080/00987913.2020.1732717

Oktavianingsih, I. (2019). Keunikan Diksi Yang Digunakan Pada Nama-Nama Makanan Tradisional Dan Modern. Jurnal Pendidikan dan Pembelajaran Bahasa Indonesia, $8(2), 72-78$.

Permadi, T. (2005). Konservasi tradisi pembuatan daluang Sebagai Salah Satu Upaya Penyelamatan Teknologi tradisional. Pemenuhan Hak Atas IImu Pengetahuan dan Teknologi, Budaya dan Seni. Diskusi Pakar, Bandung.

Poerwadarminta. (2007). Kamus Umum Bahasa Indonesia. PN Balai Pustaka.

Suroyo, S., \& Tanaamah, A. R. (2016). Peran E-Journal dalam Knowledge Sharing sebagai Basis Pengelolaan Pengetahuan di Universitas Kristen Satya Wacana. SMATIKA JURNAL, G(02), 05-12. https://doi.org/10.32664/smatika.v6i02.40 